\title{
OPTIMALISASI PRODUKTIVITAS PETERNAK BABI DI SULAWESI UTARA MELALUI RANCANG BANGUN MESIN PEMBERI PAKAN TERNAK OTOMATIS
}

\author{
Tineke Saroinsong', Alfred N Mekel², Frans Luntungan³, Marson Budiman ${ }^{4}$ \\ 1,2,3 Jurusan Teknik Mesin, Politeknik Negeri Manado, Ds. Buha, Manado, 95254 \\ ${ }^{4}$ Jurusan Teknik Elektro, Politeknik Negeri Manado, Ds. Buha, Manado, 95254 \\ Email: ${ }^{1}$ tinekesaroinsong@gmail.com
}

\begin{abstract}
Abstrak
Para peternak babi di Desa Tawaang Timur Sulawesi Utara selain berprofesi sebagai peternak, mereka juga bekerja sebagai petani kelapa. Sehingga dalam melaksanakan aktivitasnya terjadi permasalahan dalam pembagian waktu bekerja. Seperti pada kegiatan memberikan pakan yang masih secara manual. sehingga membutuhkan waktu yang lama untuk memberi pakan. Solusi dari permasalahan tersebut, peternak babi membutuhkan teknologi tepat guna untuk pemeliharaan babi, khususnya waktu memberi pakan ternak. Tujuan dari program kemitraam masyarakat Desa Tawaang Timur Sulawesi Utara untuk membuat sistem pemberi pakan ternak babi otomatis. Metode pelaksanaan yang dilakukan mulai dari mengidentifikasi masalah, perancangan dan pembuatan mesin, uji coba, kemudian memberikan pelatihan tentang cara pengoperasian dan perawatan mesin yang benar. Hasil dari program kemitraan masyarakat ini adalah memberikan teknologi tepat guna berupa mesin pakan ternak babi secara otomatis, teratur, dan terjadwal sesuai dengan jumlah dan umur dari ternak. Sehingga kualitas dan kuantitas produksi daging babi di Desa Tawaang Timur Sulawesi Utara meningkat, dan produktivitas menggunakan waktu peternak dan bertani lebih optimal.
\end{abstract}

Kata Kunci: peternak babi,mesin pakan, otomatis, program kemitraan masyarakat

\begin{abstract}
The pig farmers in eastern Tawaang Village of North Sulawesi besides working as farmers, they also work as coconut farmers. So they have difficulties in dividing the task. As in feeding activity that are still done manually, so it takes a long time for this activity. To overcome this problem, the farmers need appropriate technology in the maintenance of pigs, especially the time to feed the cattle. The purpose of the community partnership program in eastern Tawaang village is to create an automatic pig feed system. The methods of implementation is begun by identifying the problem, the second is the design and manufacture of feed machine, the third is the feed machine trial, and the las is to provide training on the right operation and maintenance of the feed machine. The resuls of this community partnership program is to provide approriate technology in the form of automatic, regular, and scheduled pig feed machine in accordance with the number and age of livestock. Finally, the quality and quantity of pork production in eastern Tawaang village in particular and in North Sulawesi in general will increase, beside that the farmer can optimize the working time.
\end{abstract}

Keywords: pig farmer, feed machine, automatic, community partnership program 


\section{PENDAHULUAN}

\section{Analis Situasi}

Kebutuhan manusia, khususnya penduduk Indonesia akan protein hewani sangat tinggi. Daging babi adalah salah satu sumber dari protein hewani. Dibandingkan negara tetangga seperti Vietnam tingkat konsumsi daging babi Indonesia masih sangat rendah. Hal ini disebabkan oleh harga yang relatif lebih mahal dibandingkan dengan Negara lain. Mahalnya harga hewan babi disebakan oleh rendahnya kemampuan peternak lokal untuk memenuhi kebutuhan daging babi sehingga kebutuhan daging babi masih di impor. Untuk mejawab tantangan tersebut peternak hewan babi diharuskan memilih metode-metode tepat guna guna untuk pemeliharaan hewan babi. Metode-metode itu antara lain metode pemilihan lahan, metode pembuatan kandang, metode pemberian pakan, metode pembersihan kandang, dan sebagainya. Tahun 2016 Redempta Wea, dkk (2016) melakukan program pengabdian pada masyarakat yaitu mendesain kandang ternak babi di perkotaan. Kemudian Mardoc C Timbulus, dkk (2017) pada tahun 2017 melaporkan penelitiannya didaerah Bolaang Mongondow pakan ternak hewan babi yang diguanakan berupa kulit kopi pengganti dedak halus sampai taraf $25 \%$ dan ransum.

Usaha peternakan babi di Sulawesi Utara terus dikembangkan secara berkelanjutan, karena kebutuhan dagaing hewan babi semakin meningkat dengan berkembangnya usaha rumah makan dan pasar yang menjual daging hewan babi. Para peternak di desa Tawang Timur selain berprofesi sebagai peternak, mereka juga bekerja sebagai petani kelapa. Sehingga dalam melaksanakan aktivitasnya terjadi permasalahan dalam pembagian waktu bekerja. Sehingga dalam kegiatan Program Kemitraan Masyarakat (PKM) ini kami memberikan solusi dengan merancang dan membuat mesin pakan ternak otomatis agar produktivitas peternakan hewan babi dapat dioptimalkan meskipun peternak menjalankan tugas lain.

\section{Permasalahan Mitra}

Peternak hewan babi Desa Tawaang Kecamatan Tenga Kabupaten Minahasa Selatan mulai berkembang pada tahun 2013. Hal ini dipicu oleh harga daging babi mulai naik saat itu. Sehingga para petani sawah, petani kelapa, bahkan beberapa pegawai negeri sipil ikut membuat kandang dan beternak hewan babi. Biasanya hewan ternak diberi pakan tiga kali dalam sehari. Ketika waktunya hewan ternak harus diberi pakan, kala itu juga mulai muncul permasalahan pembagian waktu petani harus meluangkan waktu untuk memberi pakan ternak. Yang menjadi perhatian khusus bagi hewan ternak babi setelah lepas menyusui dari induknya berumur sekitar 2 bulan sampai 4 bulan. Dimana hewan ternak diberi pakan butiran konsentrat sebanyak tiga kali dalam sehari. Setiap kandang diisi hewan ternak 10 ekor babi. kebutuhan pakan 10 ekor babi dengan umur 2-3 bulan sebanyak 3-4 kg butiran konsentrat. Kemudian meningkat ketika umur hewan babi berumur 4 bulan.
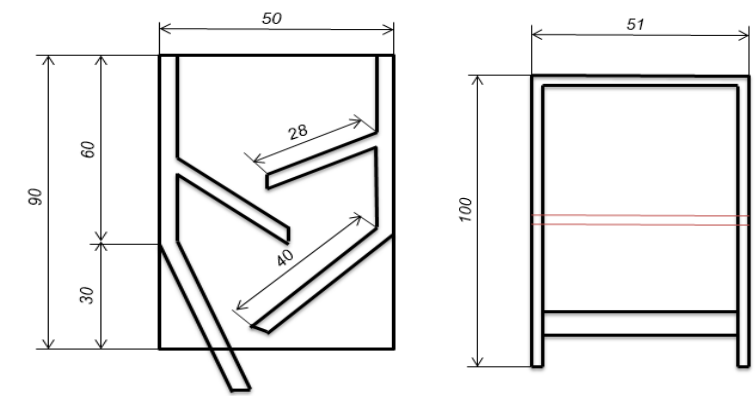

Gambar 1. Desain konstruksi tempat pakan ternak

\section{Solusi Dan Target Luaran Mitra}

Solusi dan target luaran mitra adalah merancang dan membuat mesin pemberi pakan ternak babi secara otomatis, agar produktivitas peternak hewan babi dapat di optimalkan. Berdasarkan kebutuhan mitra, alat ini diperuntukkan pada kandang hewan babi yang berumur 2 sampai 4 bulan. Jenis pakan yang diberikan adalah butiran konsentrat. Jumlah butiran konsentrat untuk 10 ekor hewan babi sebanyak 3 - 4 $\mathrm{Kg}$ untuk sekali makan. Maka dibuat mesin pakan ternak yang memenuhi permintaan mitra. Selain memberikan produk teknologi tepat guna kepada mitra, luaran lainnya adalah memberikan pelatihan singkat mengenai bahasa program untuk kontrol otomatis yang dibuat, prosedur atau cara penggunaan mesin dan cara perawatannya.
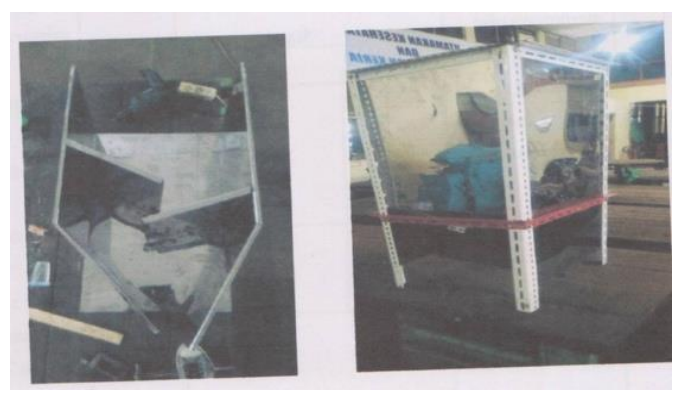

Gambar 2. Konstruksi tempat pakan ternak (Jian,2017)

Setelah konstruksinya selesai dibuat, proses selanjutnya membuat kontrol otomatis tempat pakan ternak. Alat kontrol menggunakan program Arduino IDE, mikrokontroler, box panel, real time control 
(RTC), relay 4 channel, kabel jumper, motor listrik, pegas.

\section{METODE PENELITIAN}

Rancang bangun adalah metode yang digunakan untuk menghasilkan teknologi tepat guna (TTG) mesin pakan ternak otomatis untuk masyarakat peternak hewan babi di Desa Tawaang Kabupaten Minahasa Selatan Propinsi Sulawesi Utara sebagai mitra pengabdian masyarakat. Konstruksi tempat pakan ternak berfungsi untuk menampung pakan ternak. Desain konstruksi tempat pakan ternak ditunjukkan oleh Gambar 1. Material yang digunakan adalah pelat Stainless steel tebal $0,5 \mathrm{~mm}$ dan besi siku $4 \times 4 \mathrm{~mm}$. Proses kerja pelat dilaboratorium Teknik Mesin Politeknik Negeri Manado sesuai Gambar 1, menghasilkan konstruksi tempat pakan ternak dengan kapasitas penampungan pakan sebanyak $50 \mathrm{~kg}$ seperti Gambar 2.

\section{HASIL DAN IPTEK YANG DITRANSFER KE MITRA}

Sistem kontrol otomatis yang digunakan dalam mesin pakan ternak menggunakan program Arduino IDE yang didownload dari internet, kemudian memasukan coding seperti Gambar 3. Setelah menyimpan sketch, program bisa dijalankan dengan cara mengklik symbol Verify atau dari menu sketch pilih Verify/Compile bisa juga dengan shortcut $\mathrm{Ctrl}$ + R. Apabila verify sukses akan terdapat tulisan Done Compile. Setelah selesai diverifikasi sketch bisa langsung diupload ke arduino dengan cara mengklik symbol upload atau dari menu file pilih upload, bisa juga dengan shortcut $\mathrm{Ctrl}+\mathrm{U}$. Hal-hal yang perlu diperhatikan adalah mengecek port komunikasi mana yang terhubung ke arduino, port USB harus sesuai dengan setingan pada sketch, dengan cara pilih tools - serial port. Kemudian upload file.
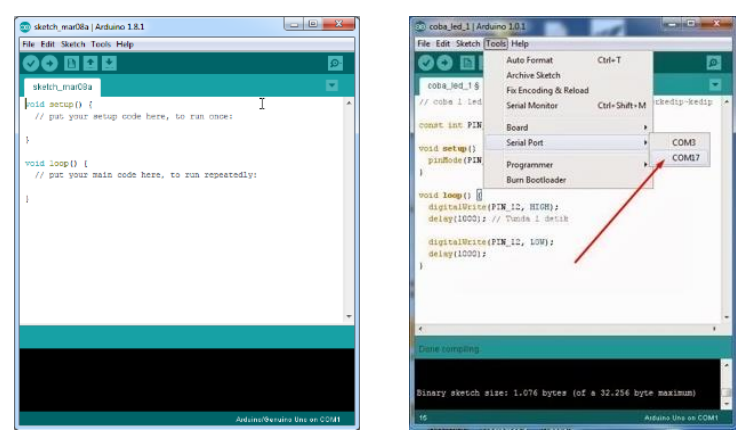

Gambar 3. Jendela Software IDE Arduino (arduino)
Konfigurasi Pin RTC dan Arduino dan interfacing Arduino dengan relay dapat dilihat pada Gambar 4 dan Gambar 5, dimana proses penyambungan mikrokontroler Arduino dengan relay menggunakan kabel jumper.
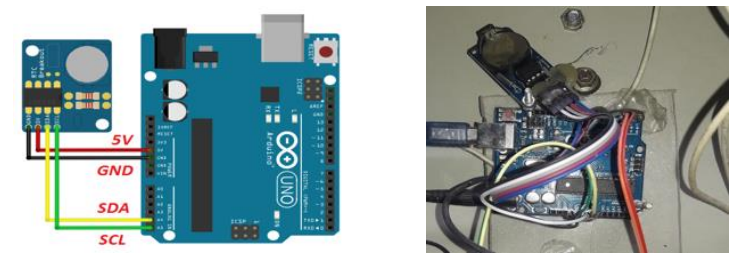

Gambar 4. Konfigurasi Pin RTC dan Arduino UNO
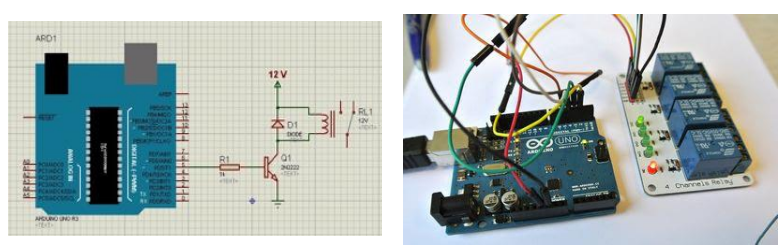

Gambar 5. Koneksi Arduino dengan relay

Jumlah atau laju aliran pakan ternak yang keluar dari penampung dikontrol pada pintu keluar pakan dibagian bawah penampung. Buka tutup pintu diatur menggunakan motor wiper dihubungkan dengan rangkaian program Arduino ditujukkan Gambar 6. Semua komponen kontrol yang digunakan yaitu arduino, RTC, dan relay dipasang dalam box panel.
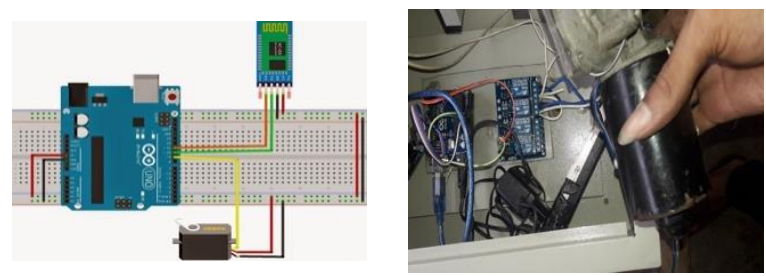

Gambar 6. Penyambungan motor wiper dengan rangkaian Arduino

Motor wiper dipasang sejajar dengan pintu penyalur pakan dan agar tidak bergeser saat motor bekerja membuka atau menutup pintu penyalur pakan ternak seperti Gambar 7.

Cara kerja sistem kontrol otomatis yang dibuat adalah waktu memberi pakan ternak babi dapat membuka tempat penampungan pakan pada jam 07.00 pagi, jam 12.00 siang dan jam 05.00 sore. Berdasarkan data dari mitra bahwa kebutuhan pakan ternak hewan babi untuk satu kali memberi pakan adalah sebanyak 3 - $4 \mathrm{~kg}$ dengan jumlah hewan ternak sebanyak 10 ekor babi pada umur hewan ternak kira-kira 2 bulan sampai 4 bulan diberi pakan butiran konsentrat. Kapasitas penampung pakan adalah $50 \mathrm{~kg}$, laju aliran pakan yang keluar sebesar $1 \mathrm{~kg} /$ detik. Sehingga pintu kontrol laju aliran 
membuka 3 detik kemudian menutup kembali. Sistem kontrol laju aliran pakan berada pada bagian bawah penampung pakan seperti yang ditunjukkan Gambar 2. Apabila laju aliran pakan mau ditambah, maka setingan waktu membuka pintu pada program Arduino diubah. Misalnya jumlah pakan yang dibutuhkan sekali makan $4 \mathrm{~kg}$, maka setingan waktu membuka pintu adalah 4 detik kemudian menutup kembali.

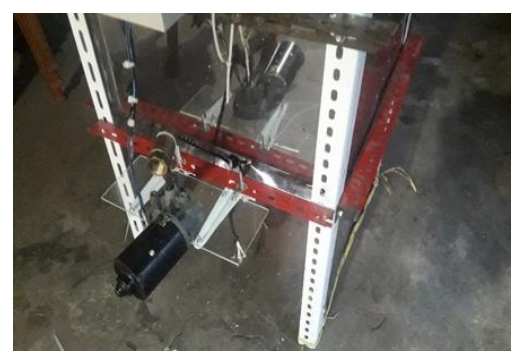

Gambar 7. Posisi komponen

Setelah rancang bangun mesin pakan ternak otomatis berhasil dibuat, selanjutnya mesin diberikan kepada mitra. Kemudian dilakukan pelatihan tentang prosedur/cara menggunakan mesin dan cara merawat mesin. Program kemitraan masyarakat ini dapat mengatasi permasalahan mitra. Meskipun para peternak menjalankan tugas lain, hewan ternaknya bisa mendapatkan pakan. Sehingga produktivitas ternak lebih meningkat dan pendapatan masyarakat juga naik.

\section{PENUTUP}

\section{Kesimpulan}

Berdasarkan hasil dan pembahasan dapat disimpulkan sebagai berikut :

$>$ Kebutuhan mitra untuk mengatasi masalah pembagian waktu beternak dan bertani adalah mesin pakan ternak hewan babi otomatis. Khususnya hewan ternak yang lepas menyusui dari induknya berumur 2 bulan sampai 4 bulan.

$>$ Konstruksi tempat pakan ternak dirancang dan dibuat menggunakan bahan stainless steel kapasitas $50 \mathrm{~kg}$. Waktu memberi pakan ternak diatur melalui program Arduino. Laju aliran pakan sebanyak $3 \mathrm{~kg}$ untuk 10 ekor hewan ternak sekali makan. Sistem kontrol melalui program Arduino dan motor Wiper untuk membuka dan menutup pintu penampungan pakan.

\section{Ucapan Terima Kasih}

Ucapan terimaksih disampaikan kepada Institusi Politeknik Negeri Manado yang telah memberikan dana pengabdian masyarakat program kemitraan masyarakat (PKM) tahun 2018.

\section{DAFTAR PUSTAKA}

Mardoc C Timbulus, Petrus R Moutong, dkk. Penampilan Produksi Ternak babi Grower yang menggunakan tepung kulit kopi sebagai bahan pengganti sebagian dedak halus pada pakan, Jurnal Zootek, Vol. 37. No. 2: 242251, 2017.

Redempta Wea, dkk. Desain Kandang ternak Babi di Perkotaan, Jurnal Pengabdian Masyarakat Peternakan, Vol. 1. No.2. 2016.

Jian Kroma, Pembuatan Tempat Pakan Ternak, Tugas akhir program Diploma 3. Politeknik Negeri Manado. 2017. 